ISSN: 1991-0037

SOUTH ASIAN JOURNAL OF AGRICULTURE

An Open Access Peer Reviewed Journal

South Asian J. Agric.

Research Article

Vol. 7, No. 1\&2, 2016-'19 : 30-33

\title{
Growth and Yield Response of BRRI dhan28 to Phosphorous Rates in Batiaghata Upazila of
} Southwestern Bangladesh

Authors: Lisobi Akter Shanta, Md. Tarekul Haque, Khan Golam Quddus and Bidhan Chandro Sarker*

Agrotechnology Discipline, Khulna University, Khulna-9208, Bangladesh

*Corresponding author: Bidhan Chandro Sarker; E-mail: bsarker2000@ gmail.com

\section{A B STR ACT}

Received:

17 November, 2018

Accepted:

23 January, 2019

Online:

31 March, 2019

Key words:

Phosphorous, BRRI

dhan28, Southwestern,

Growth and yield

attributes
The experiment was carried out during the period from January to May, 2018 at Professor Purnendu Gain Field Laboratory of Agrotechnology Discipline, Khulna University to evaluate the effect of phosphorous (P) on yield and yield attributes of BRRI dhan28. The experiment was consisted of seven $\mathrm{P}$ doses viz. $\mathrm{T}_{0}=$ without phosphorus (P), $\mathrm{T}_{1}=9 \mathrm{~kg} \mathrm{P} \mathrm{ha}{ }^{-1}, \mathrm{~T}_{2}=12 \mathrm{~kg} \mathrm{P} \mathrm{ha}^{-1}, \mathrm{~T}_{3}=15 \mathrm{~kg} \mathrm{P} \mathrm{ha}^{-1}, \mathrm{~T}_{4}=18 \mathrm{~kg} \mathrm{P} \mathrm{ha}^{-1}, \mathrm{~T}_{5}=21 \mathrm{~kg} \mathrm{P}$ $\mathrm{ha}^{-1}$ and $\mathrm{T}_{6}=24 \mathrm{~kg} \mathrm{P} \mathrm{ha}^{-1}$ as treatments. The experiment was laid out in a randomized complete block design (RCBD) with three replications. Only the grain yield and biological yield showed significant variations due to the effect of different rates of phosphorous. Others growth and yield attributes varied insignificantly. The result of this experiment showed that the highest grain yield $\left(3.82 \mathrm{t} \mathrm{ha}^{-1}\right)$ and biological yield $\left(10.87 \mathrm{t} \mathrm{ha}^{-1}\right)$ was obtained from $21 \mathrm{~kg} \mathrm{P} \mathrm{ha}^{-1}\left(\mathrm{~T}_{5}\right)$. There was an increasing trend of grain yield with the increase of phosphorous level up to $21 \mathrm{~kg} \mathrm{P} \mathrm{ha}^{-1}$ and then it declined. From the result of this experiment it could be revealed that $21 \mathrm{~kg} \mathrm{P} \mathrm{ha}^{-1}$ gives better result regarding grain yield of HYV rice variety BRRI dhan28 at Batiaghta upazila of southwestern Bangladesh.

To cite this article: Shanta, L.A., Haque, M.T., Quddus, K.G. and Sarker B.C. 2019. Growth and yield response of BRRI dhan28 to phosphorous rates in Batiaghata upazila of southwestern Bangladesh, South Asian J. Agric., 7(1\&2): 30-33.

\section{INTRODUCTION}

In Bangladesh, the agriculture sector plays a very important role in the economy of the country accounting for $15.33 \%$ of total GDP and provides employments for many people (AIS, 2017). Agriculture in Bangladesh is dominated by intensive rice cultivation. Rice covers almost $80 \%$ of the total cropped area and it constitutes about $97 \%$ of the total cereal production of the country (Bari et al., 1997). Out of total rice production in this country about $47 \%$ comes from boro rice, and the rest $8 \%$ and $45 \%$ comes from aus and aman rice, respectively (BBS, 2000). Therefore, Boro rice is the most important rice crop in Bangladesh with respect to its high yield and contribution to total rice production.

A large proportion of world's population utilizes rice (Oryza sativa L.) as staple food (Islam et al., 2010; Atera et al., 2011). Most of the cultivated rice varieties are high yielding variety (HYV) which are generally nutrient exhaustive than land races. This is resulting in problems of $\mathrm{P}, \mathrm{K}$, and $\mathrm{S}$ deficiency in soil along with inherited N deficiency (Ali et al., 1997; Saleque et al., 1998). On global scale the cultivation of rice is carried out on about 148 million hectares with production of 710 million tons (FAO, 2011). Out of this almost $90 \%$ rice production and consumption takes place in Asian countries (Islam et al., 2010). In Asia, the largest rice producing countries include China, India, Indonesia, Bangladesh and Pakistan (FAO, 2011). Among the rice growing countries, Bangladesh occupies third position in rice area and fourth position in rice production (BRRI, 2000).

However, in most of the rice growing areas, the gap between potential yield and actual yield is high. This variation is occurred by the factors such as ecological factors, bio-physical factors, management practices, and cultural and socio-economic conditions. However, the gap can be minimized through proper management of soil, fertilizer, pest, weed, and water. In fact, fertilizer management is the key that effects on potential yield in paddy.

Phosphorus as a nutrient element plays a vital role in an array of functions necessary for healthy plant growth, contributing to structural strength, crop quality, seed production, and more. The transformation of solar energy into usable compounds is also largely possible because of phosphorus. Adequate phosphorus nutrition enhances many aspects of plant physiology including the fundamental process of photosynthesis, nitrogen fixation, flowering, fruiting and maturation. Much of the $\mathrm{P}$ in the $\mathrm{P}$ compounds is not immediately available for plant uptake. Plants rarely absorb more than $20 \%$ of the total fertilizer P applied (Friesen et al., 1997). Phosphorus is most available for plant uptake when soil pH is between 6.5 and 7.5. Moreover, Khulna region is situated in saline zone therefore availability of $\mathrm{P}$ is very much critical ( $\mathrm{P}$ value of the experimental site: $11.20 \mathrm{ppm}$ ).

Phosphorus not only enhances yield but also reduces spikelet sterility. But the main problem concerning $\mathrm{P}$ fertilizers is its fixation with soil complex within a very short period of application rendering more than two thirds unavailable (Sahrawat et al., 2001).

Soil in the southwestern region of Bangladesh is quite different from other parts of Bangladesh. There is a fertilizers recommendation on AEZ basis and crop based but there is no site specific fertilizers recommendation in the southwestern coastal region. 
BRRI dhan28 most popularly cultivated rice variety in Boro season in this region. Thus, it is important to investigate the performance of BRRI dhan28 to phosphorous variation in this area. The present experiment was undertaken with the following objectives-

i. To evaluate the growth and yield response of BRRI dhan 28 at different rates of phosphorous application.

ii. To find out the optimum rate of phosphorous for growth, yield and yield attributes of BRRI dhan28 in Batiaghata upazila of southwestern Bangladesh.

\section{MATERIALS AND METHODS}

The field experiment was carried out during Boro season from January to May, 2018 at Professor Purnendu Gain Field Laboratory under Khulna University, Khulna. The soil of the experimental area was medium low land, fairly leveled, well drained and silty loam type. BRRI dhan 28 a high yielding variety of rice was used in this experiment and collected from Bangladesh Rice Research Institute, Toydebpur, Gazipur. The treatments of this experiment were $T_{0}=$ without phosphorus, $T_{1}$ $=9 \mathrm{~kg} \mathrm{Pha} a^{-1}, T_{2}=12 \mathrm{kgPha} \mathrm{T}^{-1}, T_{3}=15 \mathrm{~kg} \mathrm{Pha}^{-1}, T_{4}=18 \mathrm{kgP}$ ha ${ }^{-1}, T_{5}=21 \mathrm{~kg} \mathrm{Pha} a^{-1}$ and $T_{6}=24 \mathrm{~kg} \mathrm{P} \mathrm{ha}^{-1}$. The fertilizer TSP was used as the source of phosphorous. Other nutrients were used as per the recommended dose (AEZ basis) (FRG, 2012). All the fertilizers except urea were applied and thoroughly mixed with the soil 10 days before the final land preparation. Urea was applied as top dressed in three equal splits.

The experiment was laid out in a Randomized Complete Block Design ( $R C B D$ ), with three replications. The treatments were randomly distributed to the unit plots in each block. The unit plot size was $4.0 \mathrm{~m}$ length and $2.5 \mathrm{~m}$ wide. About 40 days old seedlings were transplanted maintaining a spacing of $25 \mathrm{~cm}$ between the rows and $15 \mathrm{~cm}$ between the hills. Intercultural operations such as gap filling, weeding, irrigation and plant protection measure were taken as and when necessary and kept usual and uniform for all the experimental plots.

Data on growth parameters such as plant height, tiller number and shoot dry weight; yield such as grain yield and straw yield; yield attributes such as effective tillers hill-1, panicle length, grain number panicle ${ }^{-1}, 1000$ grain weight and harvest index were collected and recorded.

At each sampling, data were recorded from five randomly selected hills in each unit plot. Before harvesting 5 hills were uprooted randomly from each plot for taking yield components data. The harvested crop of each plot was bundled separately, tagged properly and brought to the clean threshing floor. Grain and straw yield were recorded from whole plot basis. The grain and straw yield were adjusted to $14 \%$ moisture level. Grain yield and harvest index were calculated using the following formulae:

Grain yield (at $14 \%$ moisture content $)=\frac{10(100-\mathrm{FMC})}{100-14} \times \frac{\text { Grain yield }}{\text { Plot area }\left(\mathrm{m}^{2}\right)}$

Harvest index $(\%)=\frac{\text { Econounic yield }}{\text { Biological yield }} \times 100$

Finally the recorded data were accumulated and tabulated for analysis of variance technique using Statistical Tool for Agricultural Research (STAR) and the means among the treatments were compared by Duncan's New Multiple Range Test (DMRT) (Gomez and Gomez, 1984).

\section{RESULTS AND DISCUSSION}

Effect of phosphorous rates on growth parameters

Plant height (cm): Phosphorous rates had no significant influence on plant height (Table 1). Numerically the longest plant $(86.27 \mathrm{~cm})$ was obtained from $21 \mathrm{~kg} \mathrm{P} \mathrm{ha}^{-1}\left(\mathrm{~T}_{5}\right)$ while the shortest was recorded from control treatment $\left(\mathrm{T}_{0}\right)$. Similar result was observed by Shiferwa et al. (2012) who reported that $P$ variation had no significant effect on plant height of rice. The result also supported by Fayisa and Welbira (2016).

Tiller hill ${ }^{-1}$ : Tiller hill ${ }^{-1}$ was not affected significantly due to the variation of phosphorous rates (Table 1). However, the highest number of tiller hill-1 at harvest was found in $21 \mathrm{~kg} \mathrm{P}$ $\mathrm{ha}^{-1}\left(\mathrm{~T}_{5}\right)$ whereas, the lowest number was found in control treatment $\left(\mathrm{T}_{0}\right)$.

Shoot dry weight (g): There was no significant effect of the treatments of phosphorous rates on shoot dry weight at physiological maturity stage (Table 1 ). Numerically the highest shoot dry weight was recorded from $21 \mathrm{~kg} \mathrm{P} \mathrm{ha}^{-1}\left(\mathrm{~T}_{5}\right)$ whereas, the lowest was found in control treatment $\left(\mathrm{T}_{0}\right)$.

Table 1. Effect of phosphorous rates of growth parameters of BRRI dhan 28

\begin{tabular}{cccc}
\hline \multicolumn{1}{c}{ Treatments } & $\begin{array}{c}\text { Plant } \\
\text { height }(\mathrm{cm})\end{array}$ & $\begin{array}{c}\text { Tiller } \\
\text { No. hill }^{-1}\end{array}$ & $\begin{array}{c}\text { Shoot dry weight } \\
\text { hill }^{-1}(\mathrm{~g})\end{array}$ \\
\hline $\mathrm{T}_{0}($ without P) & 74.67 & 15.00 & 114.00 \\
$\mathrm{~T}_{1}\left(9 \mathrm{~kg} \mathrm{P} \mathrm{ha}^{-1}\right)$ & 75.67 & 17.67 & 120.00 \\
$\mathrm{~T}_{2}\left(12 \mathrm{~kg} \mathrm{P} \mathrm{ha}^{-1}\right)$ & 78.53 & 17.00 & 125.67 \\
$\mathrm{~T}_{3}\left(15 \mathrm{~kg} \mathrm{P} \mathrm{ha}^{-1}\right)$ & 78.80 & 18.33 & 122.83 \\
$\mathrm{~T}_{4}\left(18 \mathrm{~kg} \mathrm{P} \mathrm{ha}^{-1}\right)$ & 80.40 & 18.33 & 127.33 \\
$\mathrm{~T}_{5}\left(21 \mathrm{~kg} \mathrm{P} \mathrm{ha}^{-1}\right)$ & 86.27 & 19.00 & 130.17 \\
$\mathrm{~T}_{6}\left(24 \mathrm{~kg} \mathrm{P} \mathrm{ha}^{-1}\right)$ & 80.17 & 16.53 & 121.50 \\
\hline $\mathrm{LS}$ & $\mathrm{NS}$ & $\mathrm{NS}$ & $\mathrm{NS}$ \\
\hline $\mathrm{CV} \%)$ & 9.29 & 15.18 & 14.18 \\
\hline \multicolumn{4}{c}{$\mathrm{LS}=$ Level of significance, NS = Non-significant, } \\
\multicolumn{4}{c}{ CV = Co-efficient of variation }
\end{tabular}

Effect of phosphorous rates on yield and yield components Effective tiller hill-1 ${ }^{-1}$ : Number of effective tiller hill-1 did not vary significantly due to different rates of phosphorous (Table 2 ). It was noticed that the highest number of effective tiller hill ${ }^{1}$ (15.00) was produced in $24 \mathrm{~kg} \mathrm{P} \mathrm{ha}^{-1}\left(\mathrm{~T}_{6}\right)$ while the lowest was (13.67) observed in $21 \mathrm{~kg} \mathrm{Pha}^{-1}\left(\mathrm{~T}_{5}\right)$.

Panicle length (cm): Phosphorous rates had no significant effect on panicle length (Table 2). The longest panicle (20.33 $\mathrm{cm})$ was found in $21 \mathrm{~kg} \mathrm{P} \mathrm{ha}^{-1}\left(\mathrm{~T}_{5}\right)$ whereas, the shortest $(18.33$ $\mathrm{cm})$ was recorded from control treatment $\left(\mathrm{T}_{0}\right)$. The result also supported by Sahar and Burbey (2003) that without phosphorus produce shortest panicle in the low land rice.

Filled grain panicle-1: Application of different rates of phosphorous had no significant influence on number of filled grains hill ${ }^{-1}$ (Table 2). The number of filled grains hill $^{-1}$ varied from 716.67 to 1055.67 . The numerically maximum number of 
filled grain hill-1 (1055.67) was observed in $21 \mathrm{~kg} \mathrm{P}^{-1}\left(\mathrm{~T}_{5}\right)$ whereas, the minimum (716.67) was found in control treatment $\left(\mathrm{T}_{0}\right)$.

Unfilled grain panicle ${ }^{-1}$ : Application of different rates of phosphorous had no significant influence on unfilled grains hill $^{-1}$ (Table 2). The maximum number of unfilled grains hill ${ }^{-1}$ (143.33) was recorded in control treatment $\left(\mathrm{T}_{0}\right)$ whereas, the minimum (102.67) was found in $24 \mathrm{~kg} \mathrm{P} \mathrm{ha}^{-1}\left(\mathrm{~T}_{6}\right)$.

1000 grain weight (g): Different rates of phosphorous did not affect 1000-grain weight significantly (Table 2). Numerically the highest 1000 -grain weight $(22.83 \mathrm{~g})$ was recorded from 21 $\mathrm{kg} \mathrm{P} \mathrm{ha}{ }^{-1}\left(\mathrm{~T}_{5}\right)$. On the other hand the lowest 1000-grain (20.50 g) was found in control treatment $\left(\mathrm{T}_{0}\right)$.

Grain yield ( $\left.\mathbf{t ~ h a}^{-1}\right)$ : Results of the experiment regarding grain yield of BRRI dhan 28 was significantly influenced by different rates of phosphorous application (Figure 1). Though there was no significant difference among the $\mathrm{P}$ variation on yield components but numerically panicle length, grain panicle ${ }^{-1}$ and 1000 grain weight gradually increased with the increase of $\mathrm{P}$ upto $21 \mathrm{~kg} \mathrm{ha}^{-1}$ that helps to enhance grain yield. The grain yield varied from $3.20 \mathrm{t} \mathrm{ha}^{-1}$ to $3.82 \mathrm{t} \mathrm{ha}^{-1}$. The highest grain yield was obtained from $21 \mathrm{~kg} \mathrm{P} \mathrm{ha}^{-1}\left(\mathrm{~T}_{5}\right)$ which was statistically similar to $18 \mathrm{~kg} \mathrm{P} \mathrm{ha}^{-1}\left(\mathrm{~T}_{4}\right)$ and $15 \mathrm{~kg} \mathrm{P} \mathrm{ha}^{-1}\left(\mathrm{~T}_{3}\right)$. On the other hand the lowest grain yield $\left(3.20 \mathrm{t} \mathrm{ha}^{-1}\right)$ was obtained from control treatment $\left(\mathrm{T}_{0}\right)$. Similar result was also found by Zaman et al. (1995) and they reported that grain yield was increased significantly by increasing $\mathrm{P}$ application over control.

Straw yield ( $\left.\mathbf{t} \mathbf{h a}^{-1}\right)$ : Due to different rates of phosphorous straw yield was not influenced significantly (Table 2). However $18 \mathrm{~kg} \mathrm{P} \mathrm{ha}^{-1}\left(\mathrm{~T}_{4}\right)$ produced the highest straw yield $\left(7.27 \mathrm{t} \mathrm{ha}^{-1}\right)$ while the lowest $\left(6.15 \mathrm{t} \mathrm{ha}^{-1}\right)$ was obtained from $12 \mathrm{~kg} \mathrm{P} \mathrm{ha}^{-1}$ $\left(\mathrm{T}_{1}\right)$.

Table 2. Effects of different $P$ rates on yield component and yield of BRRI dhan28

\begin{tabular}{|c|c|c|c|c|c|c|c|c|}
\hline Treatment & $\begin{array}{l}\text { Effective } \\
\text { tiller hill-1 }\end{array}$ & $\begin{array}{c}\text { Panicle } \\
\text { length }(\mathrm{cm})\end{array}$ & $\begin{array}{c}\text { Filled grain } \\
\text { hill }^{-1}\end{array}$ & $\begin{array}{l}\text { Unfilled grain } \\
\text { hill }^{-1}\end{array}$ & $\begin{array}{l}\text { 1000-grain } \\
\text { weight }(\mathrm{g})\end{array}$ & $\begin{array}{l}\text { Straw yield } \\
\left(\mathrm{t} \mathrm{ha}^{-1}\right)\end{array}$ & $\begin{array}{c}\text { Biological } \\
\text { yield }\left(\mathrm{t} \mathrm{ha}^{-1}\right)\end{array}$ & $\begin{array}{c}\text { Harvest } \\
\text { index }(\%)\end{array}$ \\
\hline$\overline{T_{0}(\text { without } \mathrm{P})}$ & 14.00 & 18.33 & 908.33 & 143.33 & 20.50 & 6.17 & $9.37 b$ & 34.29 \\
\hline 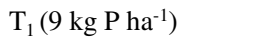 & 14.33 & 18.66 & 716.67 & 108.00 & 20.67 & 6.15 & $9.62 \mathrm{ab}$ & 35.88 \\
\hline $\mathrm{T}_{2}\left(12 \mathrm{~kg} \mathrm{P} \mathrm{ha}^{-1}\right)$ & 14.73 & 19.33 & 867.67 & 109.67 & 21.00 & 6.95 & $10.35 \mathrm{ab}$ & 32.85 \\
\hline $\mathrm{T}_{3}\left(15 \mathrm{~kg} \mathrm{P} \mathrm{ha}^{-1}\right)$ & 14.67 & 18.80 & 860.33 & 105.33 & 22.17 & 6.65 & $10.21 \mathrm{ab}$ & 34.88 \\
\hline $\mathrm{T}_{4}\left(18 \mathrm{~kg} \mathrm{P} \mathrm{ha}^{-1}\right)$ & 13.67 & 18.87 & 826.00 & 108.67 & 21.50 & 7.27 & $10.87 \mathrm{a}$ & 33.17 \\
\hline $\mathrm{T}_{5}\left(21 \mathrm{~kg} \mathrm{P} \mathrm{ha}^{-1}\right)$ & 14.67 & 20.33 & 1055.67 & 105.37 & 22.83 & 6.98 & $10.87 \mathrm{a}$ & 35.12 \\
\hline $\mathrm{T}_{6}\left(24 \mathrm{~kg} \mathrm{P} \mathrm{ha}^{-1}\right)$ & 15.00 & 18.93 & 858.00 & 102.67 & 21.00 & 6.60 & $10.00 \mathrm{ab}$ & 35.03 \\
\hline Level of significance & NS & NS & NS & NS & $\mathrm{NS}$ & $\mathrm{NS}$ & *** & $\mathrm{NS}$ \\
\hline $\mathrm{CV}(\%)$ & 11.94 & 7.44 & 15.39 & 15.58 & 4.82 & 6.46 & 4.76 & 3.70 \\
\hline
\end{tabular}

NS $=$ Non-significant, CV $=$ Co-efficient of variation, $* *=$ Significant at $1 \%$ level of significance

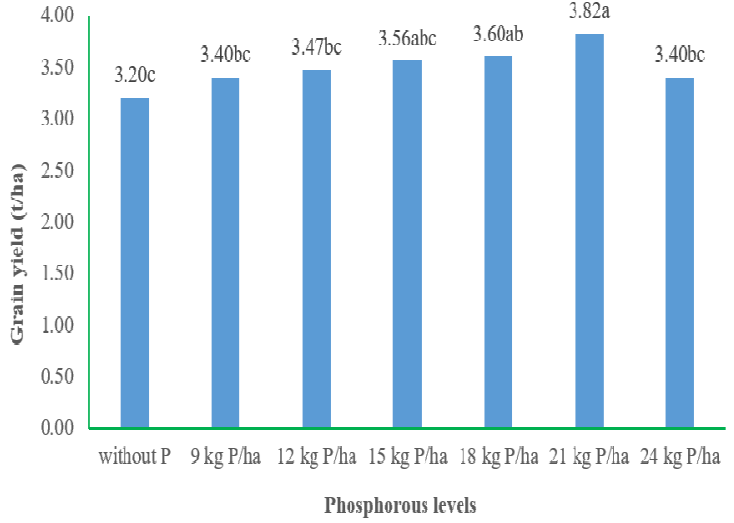

Fig. 1: Effect of phosphorus rates on grain yield of BRRI dhan28

Biological yield (t ha $\left.\mathbf{h a}^{-1}\right)$ : Different rates of phosphorous significantly influenced the biological yield (Table 2). The highest biological yield $\left(10.87 \mathrm{t} \mathrm{ha}^{-1}\right)$ was obtained from $18 \mathrm{~kg}$ $\mathrm{P} \mathrm{ha}^{-1}\left(\mathrm{~T}_{4}\right)$ which was statistically similar to all the treatments except control. The lowest biological yield $\left(9.37 \mathrm{t} \mathrm{ha}^{-1}\right)$ was obtained from control treatment $\left(\mathrm{T}_{0}\right)$.

Harvest index (\%): Harvest index did not differ significantly due to different phosphorous rates (Table 2). The highest harvest index (35.88\%) was recorded from $9 \mathrm{~kg} \mathrm{P} \mathrm{ha}^{-1}\left(\mathrm{~T}_{2}\right)$ whereas the lowest $(32.85 \%)$ was recorded from $12 \mathrm{~kg} \mathrm{P} \mathrm{ha}^{-1}$ $\left(\mathrm{T}_{2}\right)$. Singh and Bharadwaj (2008) showed that harvest index was unaffected by incremental doses of phosphorous. Similar observations were also reported by Brohi et al. (1998). 


\section{REFERENCES}

AIS (Agricultural Information Service). 2017. Krishi Diary, Khamarbari, Farmgate, Dhaka, Bangladesh.

Ali, M.M., Shahid, S.M. Kubota, D., Masunage, T. and Wakatsuki, T. 1997. Soil degradation during the period 1967-1995 in Bangladesh. II. Selected chemical characters. Soil Science and Plant Nutrition. 43: 879-890.

Atera, E.A., Onyango, J.C., Azumal, T., Asanuma, S. and Itoh, K. 2011. Field evaluation of selected NERICA rice cultivars in Western Kenya. African Journal of Agricultural. Research 6: 60-66.

Bari, M.M.G., Hossain, M.B., Kamal, A.M.A. and Samad, M.A. 1997. Biodiversity and environmental susceptibility of modem (HYV) and local aman rice variety. Bangladesh. Journal of Environmental Science (special issue) 3: 85-93.

BBS (Bangladesh Bureau of Statistics), 2000. Statistical Year Book of Bangladesh. Statistics Division, Ministry of. Plning, Govt. People's Repub. Bangladesh.

Brohi, A., Karaman, M., Aktas, A. and Savasli, E. 1998. Effect of nitrogen and phosphorus fertilization on the yield and nutrient status of rice grown on artificial siltation soil from the Kelkit River. Journal of Agriculture and Forest. 22: 585-592.

BRRI (Bangladesh Rice Research Institute). 2000. BRRI Annual Report for July 1999-June 2000. Bangladesh Rice Research Institute, Joydebpur, Gazipur, Bangladesh. pp. 50-53.

Fayisa, B.A. and Welbira, G.D. 2016. Influence of phosphorous and nitrogen fertilizer rate on grain yield of rice at kamashi zone of Benshal-gul gumuz region, Ethiopia. Journal of World Economic Research. 5(2): 8-14.

FAO (Food and Agriculture Organization). 2011. Trends of rice paddy production: monitoring the market. http://www.fao.org\esclfr|15 170 \highlight_71html.

FRG (Fertilizer Recommendation Guide). 2012. Bangladesh Agricultural Research Council (BARC). Farmgate, Dhaka. pp. 211.

Friesen, D.K., Rao, I.M., Thomas, R.J., Oberson, A. and Sanz, J.I. 1997. Phosphorus acquisition and cycling in crop and pasture systems in low fertility tropical soils. In: Ando T, Fujita K, Mae T, Matsumoto H, Mori S, Sekiya J (eds). Plant nutrition for sustainable food production and environment. Kluwer Academic Publishers, Dordrecht, pp. 493-498.

Gomez, A.K. and Gomez, A.A. 1984. Statistical Procedure for Agricultural Research. International Rice Research Institute, John Willey and Sons. New York. pp. 1-340.

Islam, M.S., Peng, S., Visperas, R.M., Sultan, M., Altaf, S.M. and Julfiquar, A.W. 2010. Comparative study on yield and yield attributes of hybrid, inbred, and NPT rice genotypes in a tropical Irrigated ecosystem. Bangladesh Journal of Agricultural Research. 35: 343-353.
Sahar, A. and N. Burbey, 2003. Effect of nitrogen, phosphorus and potassium (NPK) compound doses on the growth and yield of low land rice. J. Stigma (Indonesia), 11(1): 26-29.

Sahrawat, K.L., Abekoe, M.K., Diatta, S., Tian, G., Ishida, F., Keatinge, D. and Carsky R. 2001. Application of inorganic phosphorus fertilizer. In: Proc. Symp. Sponsored by the American Society of Agronomy, USA. 5-9 November, 2000. pp: 225-246.

Saleque, M.A., Abedin, M.J., Panaullah, G.M. and Bhuiyan, N.I. 1998. Yield and phosphorus efficiency of some lowland rice varieties at different levels of soilavailable phosphorus. Communications in Soil Science and Plant Analysis. 29: 2905-2916.

Shiferwa, N., Heluf, G., Sharma, J.J and Berhe, T. 2012 Effect of nitrogen and phosphorous application on yield attributes, grain yield and quality of rainfed rice (Nerica-3) in Gambella, southwestern Ethiopia.

Singh, P.K. and Bharadwaj, V. 2008. Effect of different nutrient levels on yield and yield attributes of hybrid and inbred rice varieties. Oryza 44(2): 137-139.

Zaman. S.K., Razzaque, M.A., Karim, S.M.R. and Bhuiyan, N.I. 1995. Rice response to phosphorus in wetland soil. Pakistan. Journal of Science and Industrial Research. 38(11-12): 438-440. 